\title{
Effect of Potassium and Crop Residue Levels on Potassium Solubilizers and Crop Yield under Maize-Wheat Rotation
}

\author{
M. Raghavendra ${ }^{*}$, Y.V. Singh ${ }^{2}$, Sunita Gaind ${ }^{3}$, M.C. Meena ${ }^{4}$ and T.K. Das ${ }^{5}$ \\ ${ }^{1}$ ICAR-Indian Institute of Soybean Research, Khandwa Road, Indore-452001, (MP), India \\ ${ }^{2}$ CCUBGA, ICAR- Indian Agricultural Research Institute, New Delhi-110 012, India \\ ${ }^{3}$ Microbiology Division, ICAR-Indian Agricultural Research Institute, \\ New Delhi-110 012, India \\ ${ }^{4}$ Soil Science and Agriculture Chemistry, ICAR-Indian Agricultural Research Institute, \\ New Delhi- 110 012, India \\ ${ }^{5}$ Agronomy Division, ICAR-Indian Agricultural Research Institute, New Delhi-110 012, India \\ *Corresponding author
}

\section{A B S T R A C T}

To study the effect of different levels $\left(0,2,4\right.$ and $\left.6 \mathrm{t} \mathrm{ha}^{-1}\right)$ of wheat and maize crop residues $(\mathrm{CR})$, potassium $(\mathrm{K})$ doses $[50,100,150 \%$ recommended $\mathrm{K}$ and $50 \% \mathrm{RDK}+\mathrm{K}$

\begin{tabular}{|c|}
\hline Keywords \\
\hline $\begin{array}{l}\text { Crop residue, Potassium, } \\
\text { Zero tillage, Yield, } \\
\text { Maize, Wheat and } \\
\text { Potassium solubilising } \\
\text { bacteria (KSB) }\end{array}$ \\
\hline Article Info \\
\hline $\begin{array}{l}\text { Accepted: } \\
\text { 02 May } 2018 \\
\text { Available Online: } \\
\text { 10 June } 2018\end{array}$ \\
\hline
\end{tabular}
solubilising bacteria (KSB)] and a combination of $\mathrm{CR}+\mathrm{K}$ doses on maize and wheat crop yield and KSB population, a field experiment was conducted during 2014-15 and 2015-16, following split plot design. The biological yield and KSB population in soil under both the test crops responded positively to $\mathrm{CR}$ and $\mathrm{K}$ management practices. Wheat and maize $\mathrm{CR}$ retention of $4 \mathrm{t} \mathrm{ha}^{-1}$ recorded significantly higher biological yield of maize and wheat, compared to their un-amended controls (11.88 and $12.04 \mathrm{t} \mathrm{ha}^{-1}$ in maize and 12.09 and 12.77 in wheat during 2014-15 and 2015-16, respectively). The viable population of KSB in inoculated soil under maize increased to 24.1 and $26.3 \times 10^{4} \mathrm{cfu} \mathrm{g}^{-1}$ soil at 60 days after sowing (DAS) and $25.7,27.9 \times 10^{4} \mathrm{cfu} \mathrm{g}^{-1}$ soil in wheat compared to their 30 DAS values of $15.5,16.3 \times 10^{4} \mathrm{cfu} \mathrm{g}^{-1}$ in maize, $15.8,16.8 \times 10^{4} \mathrm{cfu} \mathrm{g}^{-1}$ in wheat during test years of 2014-15 and 2015-16. Statistically insignificant difference in yield and KSB population was observed with $\mathrm{KSB}+\mathrm{CR}$ at 4 and $6 \mathrm{tha}^{-1}$. Application of $50 \% \mathrm{RDK}+\mathrm{KSB}$ resulted in highest biological yield $\left(13.32,14.46 \mathrm{t} \mathrm{ha}^{-1}\right.$ in maize and $13.51,14.34 \mathrm{t} \mathrm{ha}^{-1}$ in wheat). A positive correlation between biological yield of maize and wheat, yield components and KSB population was recorded at harvest stage.

\section{Introduction}

Crop residues are plant parts, left behind after the harvesting and threshing of crops. These are the waste material that need effective disposal. Over the years, their value as important nutrient resources is being realized.
India produces about 500 Million tonne (Mt) of crop residue every year, of which cereal crops (rice, wheat, maize, millets) residue's share is about $70 \%$. Generation of cereal residues is highest in Uttar Pradesh (53 Mt) followed by Punjab (44 Mt) and West Bengal (33 Mt). The total surplus crop residue in 


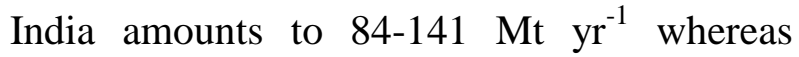
cereals contribute $23 \%$ (MNRE, 2009). Intensive cultivation has caused the mining of soil for major nutrients leading to net negative balance and multi-nutrient deficiencies in crops and that being one of the reasons for the yield decline in the Indo Gangetic Plain (IGP) region. Farmers usually dispose of the cereal crop residue through open field burning. This leads not only to emission of harmful gases such as carbon dioxide, carbon monoxide, methane, nitrous oxide, sulphur dioxide and harmful air pollutants into the atmosphere, (Gadde et al., 2009), but also causes loss of nutrients. To minimize this problem, recycling of nutrients ( $\mathrm{N}, \mathrm{P}$ and $\mathrm{K}$ ) through crop residue incorporation is one of the desired options that may lead to effective disposal and help overcome the deficiencies of other nutrients, viz., $\mathrm{S}, \mathrm{Zn}$ and $\mathrm{B}$ deficiencies, which are widespread in the IGP region (Prasad, 2005).

Potassium $(\mathrm{K})$ is the third macro-nutrient required by the crop plants (Bagyalakshmi et al., 2012) and plays a significant role in growth, yield and activation of several metabolic processes including protein synthesis, photosynthesis, enzymes, besides providing resistance to diseases and insects etc (Rehm and Schmitt, 2002). The sustainable nutrient management practices have mainly been focussed on supply of $\mathrm{N}$ and $\mathrm{P}$ while the issue of sustainable management of $\mathrm{K}$ in soil has partly been ignored. As available soil K levels have dropped, the desired requirement of the nutrient is met through chemical fertilizer. There are no reserves of K-bearing minerals in India for production of commercial K-fertilizers and the whole consumption of K-fertilizers are imported in the form of muriate of potash $(\mathrm{KCl})$ and sulphate of potash $\left(\mathrm{K}_{2} \mathrm{SO}_{4}\right)$ which involves huge amount of foreign exchange. This necessitates the need to find an alternate $K$ source that can meet the plant's K needs and maintain $\mathrm{K}$ status in soils for sustaining crop production. Potassium applied though chemical fertilization, only $1-2 \%$ is available to the plants and the rest gets bound with other minerals. Under such circumstances, biological extraction of $\mathrm{K}$ holds good promise. Potassium solubilising microorganisms have the potential to solubilise 'micas, illite and orthoclase, by excreting organic acids (Bennett et al., 1998; Barker et al., 1998). KSB have been reported to increase $\mathrm{K}$ availability in soils and result in its increased uptake by crop plants (Sheng et al., 2003). However, the performance of KSB depends upon their establishment in soil niche and may vary with type of strain, crop management practices and test crops and thus needs to be investigated. Keeping in mind the effective disposal of crop residues and importance of $\mathrm{K}$ in crop growth and its sustainable management, present investigation was undertaken with the following objectives (i) to optimize the dose of wheat and maize crop residues for enhancing the maize and wheat yield respectively. Enumeration of KSB in the crop residue and potassium amended rhizosphere soil of maize and wheat under zero till agriculture.

\section{Materials and Methods}

\section{Crop residue}

Maize and wheat crop residue was collected from the experimental farm located at Indian Agricultural Research Institute, New Delhi, India after the respective crop harvest. The residue was chopped to small size $(6-7 \mathrm{~cm})$ pieces before their incorporation in soil as mulch.

\section{Potassium solubilising bacterial strain}

$\mathrm{K}$ solubilising liquid bio-fertilizer (Bacillus decolorationis) was obtained from biofertilizer unit of Microbiology Division, ICAR- Indian Agricultural Research Institute, 
New Delhi, India and kept in refrigerator till further use. Wheat and maize seed inoculation was done with KSB applied @ $125 \mathrm{ml} \mathrm{ha}^{-1}$ seed using 5\% sugar solution as a sticker during both years of study.

\section{Experimental site and climatic conditions}

The field experiment was conducted during kharif and rabi seasons of 2014-15 and 201516 at the research farm of the ICAR-Indian Agricultural Research Institute, New Delhi, India located at $28.35^{\circ} \mathrm{N}$ latitude and $77.12^{\circ} \mathrm{E}$ longitude and $228.6 \mathrm{~m}$ above mean sea level (MSL). Delhi falls under the agro-climatic zone 'Trans-Gangetic Plains'. During wet season of 2014 and 2015, when maize was grown, total rainfall received was 395.4 and $633.10 \mathrm{~mm}$. However, during dry season of wheat cultivation (2014-15 and 2015-16) total rain fall had wide variation and it was 315.80 and $19.80 \mathrm{~mm}$ in respective seasons. The mean maximum and mean minimum temperature during maize growth was (34.27, $\left.33.47^{\circ} \mathrm{C}\right)$, and $\left(22.83,22.13^{\circ} \mathrm{C}\right)$ respectively during 2014 and 2015. For wheat the recorded mean maximum and minimum temperature was $\left(24.27,26.81^{\circ} \mathrm{C}\right)$, and $\left(10.36,9.77^{\circ} \mathrm{C}\right)$, respectively during 2014-15 and 2015-16. The soil of the experimental site was sandy loam (Bouyoucos, 1962). It had a bulk density of $1.52 \mathrm{Mg} / \mathrm{m}^{3}$ (Piper, 1950), organic carbon of $0.43 \%$ (Walkley and Balck, 1934), $\mathrm{KMnO}_{4}$ oxidizable N-143 kg ha-1 (Subbiah and Asija, 1956), $\mathrm{NaHCO}_{3}$ extractable $\mathrm{P}-13.45 \mathrm{~kg} \mathrm{ha}^{-1}$ (Olsen et al., 1954), exchangeable K- $245 \mathrm{~kg}$ ha- ${ }^{1}$ (Hanwey and Heidel, 1952), pH 8.33 and EC $0.37 \mathrm{dS} \mathrm{m}^{-1}$ (Jackson, 1973) at the start of experiment.

\section{Experimental details}

The experiment was laid out in split plot design in twenty treatment combinations. Four levels of wheat crop residue (CR) added for maize cultivation and maize crop residue for wheat cultivation (CR) included (No CR, $2 \mathrm{t}, 4$ $\mathrm{t}$ and $\left.6 \mathrm{t} \mathrm{ha}^{-1}\right)$ in main plot and five potassium levels (No K, 50\% RDK (Recommended dose of Potassium), $100 \%$ RDK, $150 \%$ RDK and $50 \%$ RDK+KSB (Potassium solubilising bacteria) in sub plots and replicated thrice. Maize (cv-PMH 4, seed rate $20 \mathrm{Kg} \mathrm{ha}^{-1}$ ) was sown at row spacing of $60 \times 30 \mathrm{~cm}$ and wheat (cv- HD CSW 18, seed rate $100 \mathrm{Kg} \mathrm{ha}^{-1}$ ) was sown at row to row distance of $20 \mathrm{~cm}$, respectively with the help of zero seed drill. Recommended dose of chemical fertilizer for maize (150:80:60 kg N, $\mathrm{P}_{2} \mathrm{O}_{5}$ and $\mathrm{K}_{2} \mathrm{O} \mathrm{ha}^{-1}$ ) and wheat (120:80:60 $\mathrm{kg} \mathrm{N}, \mathrm{P}_{2} \mathrm{O}_{5}$ and $\mathrm{K}_{2} \mathrm{O}$ $\mathrm{ha}^{-1}$ ) was placed below the seed zone while sowing as per treatment schedule given in Table 1. In maize and wheat crops full dose of $\mathrm{P}$ and $\mathrm{K}$ and half of the dose of $\mathrm{N}$ were applied as basal at sowing. The remaining $\mathrm{N}$ in wheat was top dressed in two equal splits after the first and second irrigation. In maize remaining $\mathrm{N}$ was top dressed at 35 days after sowing. Seeds of both maize and wheat crops were treated with potassium solubilising bacteria (KSB) @ $50 \mathrm{ml} /$ acre as per treatment. Sun dried and chopped residues of the wheat and maize crops of previous season were applied at cited levels to maize and wheat crops respectively by retaining it on the soil surface as mulch in all treatments except control after sowing of crops. Depth of irrigation water was kept at 6-7 cm and number of irrigation applied in maize and wheat were 4 and 5 during 2014-15 and 3 and 6 during 2015-16, respectively. To provide an ideal weed free environment to maize crop the Pendimethalin@1.00 kg a.i. ha ${ }^{-1}$ along with Atrazine (@0.75 kg a.i ha ${ }^{-1}$ was sprayed as pre-emergence at 1-2 days after sowing. To manage weeds in wheat, Isoproturon@0.75 $\mathrm{kg}$ a.i. $\mathrm{ha}^{-1}$ ) along with 2, 4D @ $0.25 \mathrm{~kg}$ a.i. $\mathrm{ha}^{-1}$ was applied as post emergence at 30 days after sowing.

Maize and wheat crop were harvested manually from the central net plot area for 
biological yield assessment. The potassium solubilising bacterial population in rhizospheric soil was determined by dilution and pour plate method using Aleksandrov medium (Hu et al., 2006). The yield data obtained from two cycles of maize and wheat crops were statistically analysed using the Ftest as per the procedure given by Gomez and Gomez (1984).

\section{Results and Discussion}

\section{Yield components and biological yield}

The yield components and biological yield of maize and wheat were significantly influenced with residue retention and $\mathrm{K}$ fertilization (Table 1). The application of $4 \mathrm{tha}^{-1}$ of crop residue (CR), being at par with $6 \mathrm{ha}^{-1}$ that recorded the highest yield components viz., cob length (15.6, $16.4 \mathrm{~cm})$, cob girth (14.8, 16 $\mathrm{cm})$, single cob weight $(152,166 \mathrm{~g})$ and biological yield $(13.09,14.17 \mathrm{t} / \mathrm{ha})$ in maize. However, in wheat, maximum spike length of 11.1 and $10.9 \mathrm{~cm}$, spiklets per spike $(22.2$, 24.9) and biological yield (13.27, $14.05 \mathrm{t} \mathrm{ha}^{-1}$ ) was recorded during both crop cycles.

Similarly $50 \% \quad \mathrm{RDK}+\mathrm{KSB}$ registered statistically higher value of yield attributes with cob length $(16.4,18.0 \mathrm{~cm})$, cob girth $(15.3,16.7 \mathrm{~cm})$, single cob weight (154.7, $169.4 \mathrm{~g})$ and biological yield $(13.32,14.46 \mathrm{t}$ $\left.\mathrm{ha}^{-1}\right)$ in maize and spike length $(10.9,12.1$ $\mathrm{cm})$, spiklets per spike $(23.3,26.3)$ and biological yield $(13.51,14.34 \mathrm{t} / \mathrm{ha})$ in wheat during both years of study. The values were at par with 100\% RDK and 150\% RDK.

\section{KSB population dynamics}

The application of crop residue and $\mathrm{K}$ to soil exerted significant effect on potassium solubilising bacterial population (Table 2). It was observed that KSB population was more during vegetative to flowering stage and thereafter declined as the crop matured. The crop residue application at $6 \mathrm{tha}^{-1}$ resulted in significantly higher population of KSB at 30 days after sowing $\left(15.5,16.3 \times 10^{4} \mathrm{cfu} \mathrm{g}^{-1}\right.$ in maize, $15.8,16.8 \times 10^{4} \mathrm{cfu}^{-1}$ in wheat) compared to 60 DAS $\left(24.1,26.3 \times 10^{4} \mathrm{cfu} \mathrm{g}^{-1}\right.$ in maize, 25.7, $27.9 \times 10^{4} \mathrm{cfu} \mathrm{g}^{-1}$ in wheat) and at harvest $\left(19.8,21.2 \times 10^{4} \mathrm{cfu} \mathrm{g}^{-1}\right.$ in maize, 19.6, $22.4 \times 10^{4} \mathrm{cfu} \mathrm{g}^{-1}$ in wheat). Though, the values were at par with $4 \mathrm{t} \mathrm{ha}^{-1}$ in both the crop and both the crop cycles.

The treatment $50 \% \mathrm{RDK}+\mathrm{KSB}$ has reported significantly maximum potassium solubilising bacterial population at 30 DAS $(15.8,16.9$ $\mathrm{x} 10^{4} \mathrm{cfu} \mathrm{g}^{-1}$ in maize and $16.2,17.2 \times 10^{4} \mathrm{cfu}$ $\mathrm{g}^{-1}$ in wheat), 60 DAS $\left(23.8,25.9 \times 10^{4} \mathrm{cfu} \mathrm{g}^{-1}\right.$ in maize and $25.7,27.6 \times 10^{4} \mathrm{cfu} \mathrm{g}^{-1}$ in wheat) and at harvest $\left(20.0,21.5 \times 10^{4} \mathrm{cfu} \mathrm{g}^{-1}\right.$ in maize and $20.1,23.1 \times 10^{4} \mathrm{cfu} \mathrm{g}^{-1}$ in wheat) over No $\mathrm{K}$ and 50\% RDK and which was on par with $100 \%$ RDK and $150 \%$ RDK in both years of experimentation.

\section{Correlation and regression study}

Correlation estimation (mean of two years data) was accomplished at phenotypic level and the results obtained are presented in Table 3 . The values of correlation denoted that biological yield $\left(\mathrm{t} \mathrm{ha}^{-1}\right)$ of maize and wheat respectively showed highly significant positive correlation with cob length $(\mathrm{cm})(\mathrm{r}$ $=0.9974 * *)$, cob girth $(\mathrm{cm})(\mathrm{r}=0.98803 * *)$, single cob weight $(\mathrm{g})\left(\mathrm{r}=0.99245^{* *}\right)$, in maize and spike length $(\mathrm{cm})\left(\mathrm{r}=0.94783^{* *}\right)$, spiklets per spike $\left(r=0.9881^{* *}\right)$ in wheat. In addition, these characters were also inter-related among themselves.

A strong and positive correlation coefficient $\left(\mathrm{r}^{2}\right)$ value was observed in potassium solubilising bacterial population and biological yield of maize $(0.948,0.932)$ and wheat $(0.980,0.965)$ in both the year of experimentation (Fig. 1). 
Table.1 Effect of crop residue and potassium management practices on yield attributes and yield of maize and wheat in conservation agriculture based maize-wheat cropping system

\begin{tabular}{|c|c|c|c|c|c|c|c|c|c|c|c|c|c|c|}
\hline \multirow[t]{3}{*}{ Treatment } & \multicolumn{8}{|c|}{ Maize } & \multicolumn{6}{|c|}{ Wheat } \\
\hline & \multicolumn{2}{|c|}{ Cob length $(\mathrm{cm})$} & \multicolumn{2}{|c|}{ Cob girth $(\mathrm{cm})$} & \multicolumn{2}{|c|}{ Single cob weight $(\mathrm{g})$} & \multicolumn{2}{|c|}{ Biological yield $\left(\mathrm{t} \mathrm{ha}^{-1}\right)$} & \multicolumn{2}{|c|}{ Spike length $(\mathrm{cm})$} & \multicolumn{2}{|c|}{ Spiklets/spike } & \multicolumn{2}{|c|}{ Biological yield $\left(\mathrm{t} \mathrm{ha}^{-1}\right)$} \\
\hline & 2014 & 2015 & 2014 & 2015 & 2014 & 2015 & 2014 & 2015 & 2014-15 & $2015-16$ & 2014-15 & 2015-16 & 2014-15 & $2015-16$ \\
\hline \multicolumn{15}{|c|}{ Crop residue management practices (CRM) } \\
\hline No CR & 10.9 & 11.8 & 12.3 & 12.8 & 138.0 & 147.7 & 11.88 & 12.84 & 8.9 & 9.5 & 17.2 & 19.9 & 12.09 & 12.77 \\
\hline 2 t/ha CR & 13.2 & 14.8 & 13.3 & 13.5 & 141.0 & 152.5 & 12.46 & 13.51 & 9.8 & 10.2 & 18.9 & 21.6 & 12.65 & 13.35 \\
\hline 4 t/ha CR & 15.6 & 16.4 & 14.8 & 16.0 & 152.0 & 166.1 & 13.09 & 14.17 & 11.1 & 12.2 & 22.2 & 24.9 & 13.27 & 14.05 \\
\hline 6 t/ha CR & 15.1 & 16.0 & 14.3 & 15.2 & 149.4 & 163.6 & 13.05 & 14.08 & 10.9 & 12.0 & 21.1 & 23.9 & 13.21 & 13.98 \\
\hline SEm \pm & 0.3 & 0.2 & 0.2 & 0.3 & 0.8 & 1.4 & 0.15 & 0.16 & 0.3 & 0.2 & 0.4 & 0.4 & 0.14 & 0.15 \\
\hline LSD $(P=0.05)$ & 1.0 & 0.8 & 0.7 & 1.1 & 2.9 & 4.8 & 0.52 & 0.54 & 0.9 & 0.6 & 1.3 & 1.4 & 0.48 & 0.53 \\
\hline \multicolumn{15}{|c|}{ Potassium management practices (PM) } \\
\hline No K & 8.6 & 7.6 & 11.0 & 9.8 & 125.3 & 132.6 & 10.95 & 11.78 & 8.7 & 9.1 & 14.0 & 15.7 & 11.20 & 11.72 \\
\hline $50 \%$ RDK & 12.7 & 13.4 & 12.9 & 13.3 & 141.3 & 152.5 & 12.35 & 13.35 & 9.6 & 10.2 & 18.5 & 21.5 & 12.46 & 13.09 \\
\hline $100 \%$ RDK & 15.5 & 17.5 & 14.8 & 16.4 & 152.3 & 167.1 & 13.27 & 14.36 & 10.9 & 11.8 & 22.1 & 25.1 & 13.47 & 14.30 \\
\hline $150 \%$ RDK & 15.4 & 17.2 & 14.4 & 15.8 & 151.8 & 165.9 & 13.22 & 14.29 & 10.7 & 11.7 & 21.3 & 24.3 & 13.38 & 14.24 \\
\hline $50 \%$ RDK+KSB & 16.4 & 18.0 & 15.3 & 16.7 & 154.7 & 169.4 & 13.32 & 14.46 & 10.9 & 12.1 & 23.3 & 26.3 & 13.51 & 14.34 \\
\hline SEm \pm & 0.4 & 0.4 & 0.3 & 0.4 & 1.4 & 1.6 & 0.10 & 0.14 & 0.2 & 0.2 & 0.7 & 0.7 & 0.12 & 0.13 \\
\hline LSD $(P=0.05)$ & 1.0 & 1.1 & 0.9 & 1.3 & 4.0 & 4.7 & 0.28 & 0.39 & 0.7 & 0.6 & 2.1 & 2.1 & 0.34 & 0.39 \\
\hline CRM x PM & NS & NS & NS & NS & NS & NS & NS & NS & NS & NS & NS & NS & NS & NS \\
\hline
\end{tabular}

CR: Crop residue, RDK: Recommended dose of potassium, KSB: Potassium solubilising bacteria, DAS: Days after sowing, NS: Non Significant 
Table.2 Effect of potassium and crop residue management practices on potassium solubilising bacterial population dynamics in rhizospheric soil of maize and wheat in conservation agriculture based cropping system

\begin{tabular}{|c|c|c|c|c|c|c|c|c|c|c|c|c|}
\hline \multirow{4}{*}{ Treatment } & \multicolumn{12}{|c|}{ Potassium solubilising bacteria (x10 ${ }^{4} \mathrm{cfu}^{-1}$ ) } \\
\hline & \multicolumn{6}{|c|}{ Maize } & \multicolumn{6}{|c|}{ Wheat } \\
\hline & \multicolumn{3}{|c|}{2014} & \multicolumn{3}{|c|}{2015} & \multicolumn{3}{|c|}{$2014-15$} & \multicolumn{3}{|c|}{$2015-16$} \\
\hline & $\begin{array}{c}30 \\
\text { DAS }\end{array}$ & $\begin{array}{c}60 \\
\text { DAS }\end{array}$ & $\begin{array}{c}\text { At } \\
\text { harvest }\end{array}$ & $\begin{array}{c}30 \\
\text { DAS }\end{array}$ & $\begin{array}{c}60 \\
\text { DAS }\end{array}$ & $\begin{array}{c}\text { At } \\
\text { harvest }\end{array}$ & $\begin{array}{c}30 \\
\text { DAS }\end{array}$ & $\begin{array}{c}60 \\
\text { DAS }\end{array}$ & $\begin{array}{c}\text { At } \\
\text { harvest }\end{array}$ & $\begin{array}{c}30 \\
\text { DAS }\end{array}$ & $\begin{array}{c}60 \\
\text { DAS }\end{array}$ & $\begin{array}{c}\text { At } \\
\text { harvest }\end{array}$ \\
\hline \multicolumn{13}{|c|}{ Crop residue management practices (CRM) } \\
\hline No CR & 11.0 & 17.2 & 14.7 & 11.4 & 18.6 & 15.5 & 12.0 & 19.4 & 16.0 & 12.6 & 20.7 & 18.2 \\
\hline 2 t/ha CR & 13.4 & 20.9 & 17.3 & 13.9 & 22.6 & 18.2 & 13.7 & 22.9 & 17.4 & 14.3 & 24.4 & 19.7 \\
\hline 4 t/ha CR & 14.7 & 23.5 & 19.1 & 15.7 & 25.4 & 20.3 & 14.9 & 25.1 & 18.9 & 15.6 & 26.7 & 21.8 \\
\hline $6 \mathrm{t} / \mathrm{ha} \mathrm{CR}$ & 15.5 & 24.1 & 19.8 & 16.3 & 26.3 & 21.2 & 15.8 & 25.7 & 19.6 & 16.8 & 27.9 & 22.4 \\
\hline SEm \pm & 0.34 & 0.57 & 0.47 & 0.40 & 0.52 & 0.52 & 0.33 & 0.49 & 0.34 & 0.39 & 0.55 & 0.30 \\
\hline $\operatorname{LSD}(P=0.05)$ & 1.19 & 1.96 & 1.62 & 1.38 & 1.80 & 1.81 & 1.14 & 1.71 & 1.19 & 1.37 & 1.89 & 1.02 \\
\hline \multicolumn{13}{|c|}{ Potassium management practices (PM) } \\
\hline No K & 10.1 & 16.7 & 13.4 & 10.5 & 18.1 & 14.2 & 8.5 & 18.3 & 14.0 & 8.9 & 19.6 & 16.1 \\
\hline 50\% RDK & 11.9 & 20.2 & 16.8 & 12.4 & 21.8 & 17.8 & 14.2 & 22.0 & 16.8 & 14.9 & 23.5 & 19.0 \\
\hline $100 \%$ RDK & 15.4 & 23.4 & 19.5 & 16.2 & 25.5 & 20.7 & 16.1 & 25.3 & 19.8 & 16.8 & 27.3 & 22.7 \\
\hline $150 \% \mathrm{RDK}$ & 15.0 & 23.0 & 18.8 & 15.7 & 24.8 & 19.9 & 15.6 & 24.8 & 19.3 & 16.3 & 26.6 & 21.8 \\
\hline $\begin{array}{l}50 \% \\
\text { RDK+KSB } \\
\end{array}$ & 15.8 & 23.8 & 20.0 & 16.9 & 25.9 & 21.5 & 16.2 & 25.7 & 20.1 & 17.2 & 27.6 & 23.1 \\
\hline SEm \pm & 0.47 & 0.59 & 0.58 & 0.54 & 0.61 & 0.60 & 0.42 & 0.35 & 0.45 & 0.45 & 0.41 & 0.53 \\
\hline LSD $(P=0.05)$ & 1.36 & 1.69 & 1.68 & 1.56 & 1.76 & 1.71 & 1.22 & 1.02 & 1.29 & 1.31 & 1.19 & 1.52 \\
\hline CRM x PM & NS & NS & NS & NS & NS & NS & NS & NS & NS & NS & NS & NS \\
\hline
\end{tabular}


Table.3 Pearson correlation (r-values) among different yield components and biological yield (two years mean data) of maize and wheat under conservation agriculture based maize-wheat cropping system

\begin{tabular}{|c|c|c|c|c|c|c|c|}
\hline & $\begin{array}{l}\text { Maize cob } \\
\text { length (cm) }\end{array}$ & $\begin{array}{l}\text { Maize cob girth } \\
\qquad(\mathrm{cm})\end{array}$ & $\begin{array}{l}\text { Maize single } \\
\text { cob weight } \\
\text { (g) }\end{array}$ & $\begin{array}{l}\text { Wheat } \\
\text { spike } \\
\text { length } \\
\text { (cm) }\end{array}$ & $\begin{array}{c}\text { Wheat } \\
\text { spiklets/spike }\end{array}$ & $\begin{array}{c}\text { Maize } \\
\text { biological } \\
\text { yield (t } \\
\text { ha }^{-1} \text { ) }\end{array}$ & $\begin{array}{c}\text { Wheat } \\
\text { biological } \\
\text { yield }\left(\mathbf{t ~ h a}^{-1}\right)\end{array}$ \\
\hline $\begin{array}{c}\text { Maize cob } \\
\text { length } \\
\text { (cm) }\end{array}$ & 1 & $0.99134 * *$ & $0.98996 * *$ & $0.94924 * *$ & $0.99134 * *$ & $0.9974 * *$ & $0.99657 * *$ \\
\hline $\begin{array}{l}\text { Maize cob girth } \\
\qquad(\mathrm{cm})\end{array}$ & $0.99134 * *$ & 1 & $0.99482 * *$ & $0.95604 * *$ & $0.99827 * *$ & $0.98803 * *$ & $0.99124^{* *}$ \\
\hline $\begin{array}{l}\text { Maize single cob } \\
\text { weight (g) }\end{array}$ & $0.98996 * *$ & $0.99482 * *$ & 1 & $0.947 * *$ & $0.99424 * *$ & $0.99245 * *$ & $0.99331 * *$ \\
\hline $\begin{array}{l}\text { Wheat spike } \\
\text { length (cm) }\end{array}$ & $0.94924 * *$ & $0.95604 * *$ & $0.947 * *$ & 1 & $0.94791 * *$ & $0.94351 * *$ & $0.94783^{* *}$ \\
\hline $\begin{array}{c}\text { Wheat spiklets } \\
\text { /spike }\end{array}$ & $0.99134 * *$ & $0.99827 * *$ & $0.99424 * *$ & $0.94791 * *$ & 1 & $0.98722 * *$ & $0.9881 * *$ \\
\hline $\begin{array}{l}\text { Maize biological } \\
\text { yield ( } \text { ha }^{-1} \text { ) }\end{array}$ & $0.9974 * *$ & $0.98803 * *$ & $0.99245 * *$ & $0.94351 * *$ & $0.98722 * *$ & 1 & $0.99882 * *$ \\
\hline $\begin{array}{c}\text { Wheat biological } \\
\text { yield }\left(\mathbf{t} \mathbf{h a}^{-1}\right)\end{array}$ & $0.99657 * *$ & $0.99124 * *$ & $0.99331 * *$ & $0.94783^{* *}$ & $0.9881 * *$ & $0.99882 * *$ & 1 \\
\hline
\end{tabular}

**Significant at $0.01 \%$ level of significance 
Fig.1 Simple regression between potassium solubilising bacterial population at harvest and biological yield of maize and wheat under conservation agriculture based maize-wheat cropping system
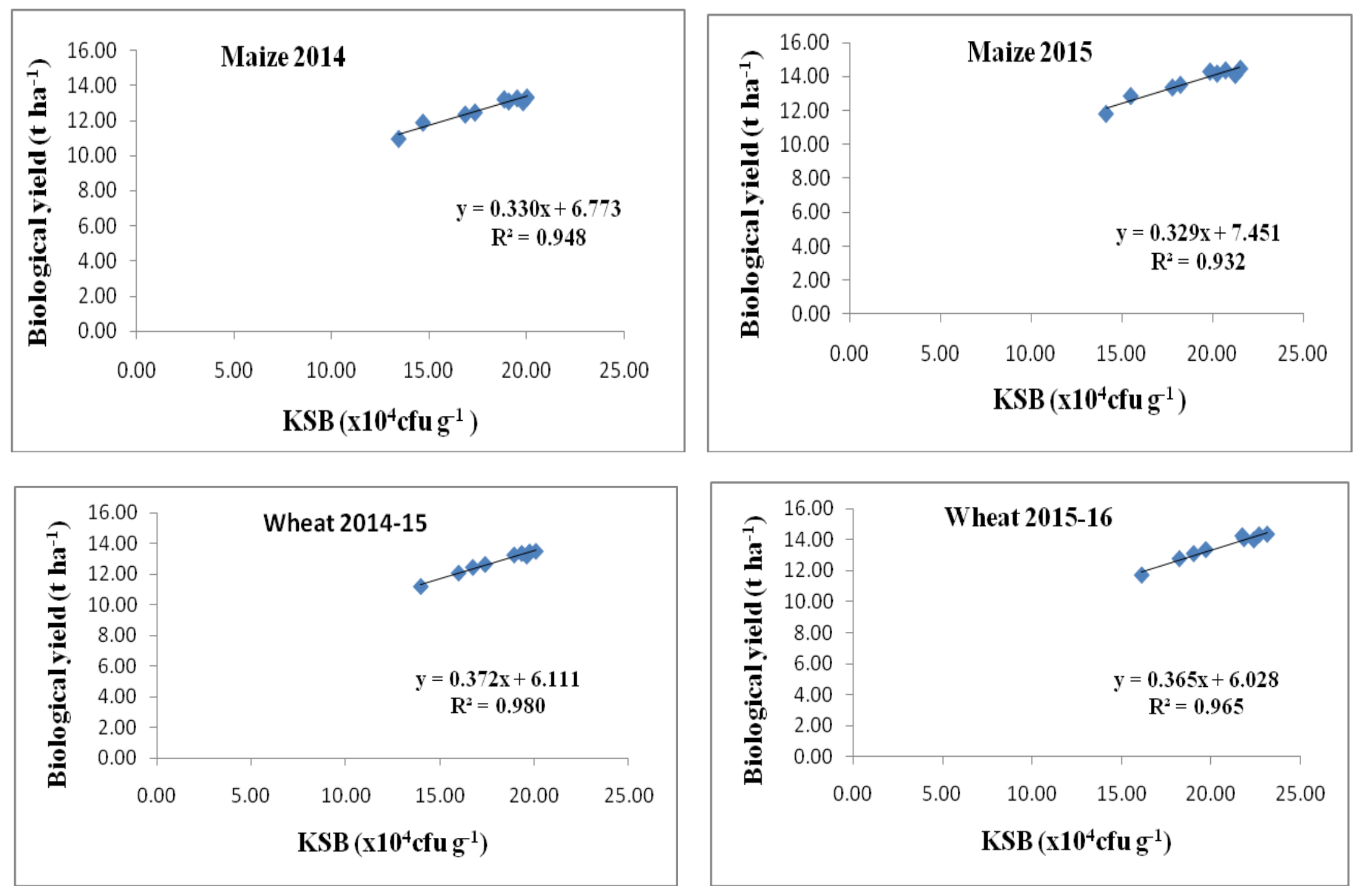
All the yield components and biological yield of maize and wheat crops were significantly influenced by crop residue, $\mathrm{K}$ application and seed inoculation of plant-growth-promoting rhizobacteria (KSB), with the highest yield components observed in $4 \mathrm{t} / \mathrm{ha}$ and $6 \mathrm{t} / \mathrm{ha}$ crop residue plot, the increased yield components and biological with crop residue application might be due to no-tillage management, in conjunction with application of large quantities of straw mulch on the soil surface maintain good and favourable soil moisture, moderate soil temperature, and improved soil water and nutrient conditions, increased saturated and unsaturated hydraulic conductivities, earthworm population, soil water retention, total soil porosity, and macroporosity (Blanco-Canqui and Lal, 2006), might have been the reasons. Sharma et al., (2009), Jat (2010) and Saad et al., (2015) also reported the higher values of yield attribute and biological yield under residue application. The application of $50 \%$ RDK in conjunction with seed inoculation of plant-growthpromoting rhizobacteria (KSB) has significantly improved all the yield attributes and biomass yield of both the crops under zero till condition were mainly due to the mobilization of $\mathrm{K}$ from soil because of secretion of organic acids, protons, siderophores, exopolysaccharides and organic ligands by bacterial strain, which in turn increased availability of both essential macro and micro nutrients for crop uptake in soil by maintaining good health of soil. These findings are also conformity with Muralikaman (1996), Basak and Biswas (2009) and Basavesha et al., (2016). The increased yield with $\mathrm{K}$ fertilization might be due to increased availability, absorption and translocation of $\mathrm{K}$ nutrient. As the $\mathrm{K}$ is essential for grain development, the favourable effect of high doses of $\mathrm{K}$ on growth and yield attributes was mainly responsible for higher biological yield. Significant effects of K application in sesame, mustard, groundnut, maize wheat were reported by Yadav et al., (2012) and Jat et al., (2014). Potassium solubilising bacterial population was significantly improved with crop residue retention in soil and their population changed from 30 DAS to at crop harvest might be due to crop residues had a stronger impact on soil microbial activity interns of residue decomposition and higher root activity upto 60 DAS there after it decreases and also micro-climate created by zero tillage with residue, availability of substrate provided by crop residues and micro-organism density as earlier reported by Balota et al., (1998), Valpassos et al., (2001) and Chaitanya et al., (2013). K solubilising bacterial population activity was increased markedly by $\mathrm{K}$ - mineral fertilization along with seed inoculation of KSB in both crops and variability of microbial population in the present study might have been resulted from growth hormone production and release of organic acid by KSB inoculants with seed in soil. This result is also comparable with Basavesh (2013) and fertilizer directly improve the plant root growth and development and root exuded provide the required nutrients for microbes it intern enhance microbial growth and may affect the composition of microbial communities and similar result was also reported by (Khonje et al., 1989; Naher et al., 2013).

The highly significant correlation was found between different yield attributes and biological yield of maize and wheat. Yield formation in cereals is a complex coordinated process that involves the build-up and subsequent re-assimilation of yield components. These processes are under genetic control and strongly affected by environmental conditions and other management practices. Similar correlation trend was also reported by Inamullah et al., (2011) in maize and Limon et al., (2000) and Nasri et al., (2014) in wheat. 
The findings of this experimental trial suggest that crop residues can partially (if not fully) compensate for the low fertility status of the agricultural soils caused due to high cost of chemical fertilizer. A combination of chemical K-fertilizer and crop residues can be termed as an ideal technique to maintain the fertility of soil in both short and long terms. Although chemical K-fertilizer resulted in best results, it seems logical to conclude that a combination of crop residues with it will have more benefits in the long run due to slow decomposition of residues which will enhance biological (KSB) activity, improve nutrients availability and biological yield of maize and wheat under zero till environment in the following years.

\section{Acknowledgements}

Our sincere thanks are due to Head and Professor, Division of Agronomy, Head, Division of Soil science and Agriculture Chemistry, ICAR-Indian Agricultural Research Institute, New Delhi, India for their advice and support and UGC, Govt. of India for providing financial support in the form of doctoral fellowship to first author.

\section{References}

Bagyalakshmi, B., Ponmurugan, P., and Marimuthu, S. 2012. Influence of potassium solubilizing bacteria on crop productivity and quality of tea (Camellia sinensis). African Journal of Agricultural Research 7(30): 42504259.

Balota, E.L., Colozzi-filho, A., Andrade, D.S., and Hungria, M. 1998. Biomassa microbiana e sua atividade em solos sob diferentes sistemas de preparo e sucessão de Culturas. R. Bras. Ci. Solo 22: 641-649.

Barker, W.W., Welch, S.A., Chu, S., Banfield, J.F. 1998. Experimental observations of the effects of bacteria on aluminosilicate weathering. $A m$ Mineral 83: 1551-1563.

Basak, B.B., and Biswas, D.R. 2009. Influence of potassium solubilising microorganism (Bacillus mucilaginosus) and waste mica on potassium uptake dynamics by Sudan grass (Sorghum vulgare Pers.) grown under two Alfisols. Plant Soil 317: 235255.

Basavesha, K.N. 2013. Studies on bacteria solubilising both potassium and phosphorus and their effect on maize (Zea mays L.). M Sc. Thesis. UAS Dharwad.

Basavesha, K.N., Savalgi, V.P., Sreenivasa, M.N., and Manjunatha, H. 2016. Impact of bacteria solubilizing both potassium and phosphorus on growth and yield of maize (Zea mays L.). Research in Environment and Life Sciences 9(4) 464-465.

Bennett, P.C., Choi, W.J., and Rogera, J.R. 1998. Microbial destruction of feldspars. Mineral Mngt., 8(62A): 149150.

Blanco-Canqui, H.R., Lal, W.M., Post, R.C., Izaurralde, and Owens, L.B. 2006. Rapid changes in soil carbon and structural properties due to stover removal from no-till corn plots. Soil Sci. 171: 468-482.

Bouyoucos, G.J. 1962. Hydrometer method improved for making particle size analysis of soils. Agronomy Journal 54: 464-465.

Dobermann, A., and Fairhurst, T.H. 2000. Rice: Nutrient Disorders and Nutrient Management. Potash and Phosphate Institute (PPI), Potash and Phosphate Institute of Canada (PPIC) and International Rice Research Institute (IRRI), East and South Asia Programs of PPI and PPIC, Singapore 
FAI, 2007. Fertiliser Statistics 2006-2007. The Fertiliser Association of India, New Delhi.

Gadde, B., Bonnet, S., Menke, C. and Garivait S. 2009. Air pollutant emissions from rice straw open field burning in India, Thailand and the Philippines. Environmental Pollution, 157: 1554-1558.

Gomez, K.A., and Gomez, A.A. 1984. Statistical Procedures for Agricultural Research. John Wiley and Sons, New York.G.

Hanway, J. J., and Heidel, H. 1952. Soil analysis methods as used in Iowa State College, Soil Testing Laboratory. Iowa Agriculture 54: 1-31.

Hu, X.F., Chen, J. and Guo, J.F. 2006. Two phosphate and potassium solubilising bacteria isolated from Tiannu mountain, Zhejiang, China. World Journal of Microbial Biotechnology 22: 983-990.

Inamullah, Rehman, N., Shah, N.H., Arif, M., Siddiq, M., and Ishaq, A.M. 2011. Correlations among grain yield and yield attributes in maize hybrids at various nitrogen levels. Sarhad Journal of Agriculture 27: 4.

Jackson, M.L. 1973. Soil chemical analysis (II ed.). Prentice Hall of India Pvt. Ltd., New Delhi, pp. 498.

Jat, G., Majumdar, S.P., Jat, N.K., and Mazumdar, S. 2014. Effect of potassium and zinc fertilizer on crop yield, nutrient uptake and distribution of potassium and zinc fractions in Typic Ustipsamment. Indian Journal of Agricultural Sciences 84 (7): 832-8.

Khonje, D.J., Varsa, E.C., and Klubek, B. 1989. The acidulation effects of nitrogenous fertilizers on selected chemical and microbiological properties of soil. Comm Soil Sci Plant Anal 20: 1377-1395.

Limon, O.A.L., Sayre, K.D. and Francis CA 2000. Wheat nitrogen use efficiency in a bed planting system in Northwest Mexico. Agronomy Journal 92: 303308.

McAfee, J. 2008. Potassium, a Key Nutrient for Plant Growth. Department of Soil and Crop Sciences http://jimmcafee. tamu.edu/files/potassium.

MNRE, 2009. Ministry of new and renewable energy resources, Government of India, www.mnre.gov.in/biomass-resources

Muralikannan, M. 1996. Biodisolution of silicate, phosphate and potassium by silicate solubilizing bacteria in rice ecosystem. M.Sc. (Agri.) Thesis, Tamil Nadu Agric. Univ., Combatore.

Naher, U.A., Radziah, O. and Ali, Q.P. 2013. Culturable total and beneficial microbial occurrences in long-term nutrient deficit wetland rice soil. Austrailian Journal of Crop Science 7(12): 1848-1853.

Nasri, R., Ali, K., Farzad, P., Saeed, V. and Mehrshad, B. 2014. Correlation, path analysis and stepwise regression in yield and yield component in wheat (Triticum aestivum L.) under the temperate climate of ilam province, Iran. Indian Journal of Fundamental and Applied Life Sciences 4 (4): 188198.

Olsen, B.C., Cole, C.V., Watenabe, F.S., and Dean, L.A. 1954. Estimation of available phosphorus by extraction with sodium carbonate, USDA Circ. No. 939, pp 19.

Powell, J.M., and Unger, P.W. 1997. Alternatives to Crop Residues for Soil Amendment. In: Renard, C (ed.), Crop Residues in Sustainable Mixed Crop/Livestock Farming Systems. 215240.

Prasad, R. 2005. Rice-wheat cropping system. Advances in Agronomy 86: 255-339.

Rehm, G., and Schmitt, M. 2002. Potassium for crop production. Regents of the University of Minnesota. United States of America. http://www.extension.umn. 
edu/distribution/cropsystems/dc6794.ht $\mathrm{ml}$.

Saad, A.A., Das, T.K., Rana, D.S., and Sharma, A.R. 2015. Productivity, resource-use efficiency and economics of maize (Zea mays)-wheat (Triticum aestivum)-greengram (Vigna radiata) cropping system under conservation agriculture in irrigated north-western Indo-Gangetic plains. Indian Journal of Agronomy 60 (4): 502-510.

Sharma, P., Vikas, A., Maruthi, G.R., Sankar, and Singh, B. 2009. Influence of tillage practices and mulching options on productivity, economics and soil physical properties of maize (Zea mays)-wheat (Triticum aestivum) system. Indian Journal of Agricultural Sciences 79 (11): 865-70.

Sheng, X.F., Xia, J.J., and Cheng, J. 2003. Mutagenesis of the Bacillus edaphicus strain NBT and its effect on growth of chilli and cotton. Agric. Sci., China. 32: 258-265.

Subbiah, B.V., and Asija, G.L. 1956. A rapid procedure for the estimation of available nitrogen in soils. Current Science 25 (8): 259-260.

Valpassos, M.A.R., Cavalcante, E.G.S., Cassiolato, A.M.R., and Alves, M.C. 2001. Effects of soil management systems on soil microbial activity, bulk density and chemical properties. Pesq. agropec. bras., Brasília 36 (12): 15391545.

Walkley, A.J., and Black, C.A. 1934. Estimation of soil organic carbon by the chronic acid titration method. Soil Science 37: 29-38.

Yadav, S.S., Tikkoo, A., and Singh, J.P. 2012. Effect of potassium fertilization on pearl-millet cropping system in coarse textured soils of southern Haryana. Journal of the Indian Society of Soil Science 60 (2): 145-9.

\section{How to cite this article:}

Raghavendra, M., Y.V. Singh, Sunita Gaind, M.C. Meena and Das, T.K. 2018. Effect of Potassium and Crop Residue Levels on Potassium Solubilizers and Crop Yield under MaizeWheat Rotation. Int.J.Curr.Microbiol.App.Sci. 7(06): 424-435. doi: https://doi.org/10.20546/ijcmas.2018.706.048 